Research article

\title{
REPARATION OF CHONDRAL DEFECTS IN RABBITS BY AUTOLOGOUS AND ALLOGENOUS CHONDROCYTES SEEDED ON COLLAGEN/HYALURONAN SCAFFOLD OR SUSPENDED IN FIBRIN GLUE
}

\author{
HORŇNÁK Slavomír ${ }^{1}$, HARVANOVÁ Denisa ${ }^{2 *}$, LEDECKÝ Valent ${ }^{1}$, HLUCHÝ \\ Mariann $^{1}$, VALENČÁKOVÁ-AGYAGOSOVÁ Alexandra ${ }^{1}$, AMRICHOVÁ Judita ${ }^{2}$, \\ ROSOCHA Ján ${ }^{2}$, VAŠKO Gabriel ${ }^{3}$, ŠVIHLA Róbert ${ }^{3}$, PETROVIČ Vladimír ${ }^{1}$
}

${ }^{1}$ University of Veterinary Medicine and Pharmacy, Clinic of Small Animals, Komenského 73, 04181 Košice, Slovak Republic; ${ }^{2}$ Tissue Bank, Pavol Jozef Šafárik University, Faculty of Medicine and University Hospital of L. Pasteur, Trieda SNP 1, 04066 Košice, Slovak Republic; ${ }^{3}$ Department of Orthopaedics and Traumatology of Locomotory Apparatus, Pavol Jozef Šafárik University Faculty of Medicine and University Hospital of L. Pasteur, Trieda SNP 1, 04190 Košice, Slovak Republic

(Received 08 January 2014; Accepted 28 January 2014)

The topic of the study was to verify in vivo survival of in vitro cultured autologous and allogenous chondrocytes suspended in a fibrin glue Beriplast ${ }^{\circledR}$ or seeded on Collagen type I-Hyaluronan (Col type I-HYA) scaffolds for the regeneration of articular cartilage defects in rabbits. The study was carried out on 15 domestic rabbits randomly assigned to five groups ( $\mathrm{n}=3$ in each) with different treatments of artificially created chondral defects (ChD's). These defects were made in a non-load-bearing area of medial condyle of the distal femur, and were treated as follows: $1^{\text {st }}$ and $3^{\text {rd }}$ group: the ChD's were filled with autologous or allogenous chondrocytes seeded on Col type I-HYA scaffolds, respectively. The scaffolds were fixed to the ChD's by fibrin glue Beriplast ${ }^{\mathbb{R}} ; 2^{\text {nd }}$ and $4^{\text {th }}$ group: the ChD's were filled with a suspension of autologous or allogenous chondrocytes in fibrin glue Beriplast ${ }^{\circledR}$, respectively, and they were immediately covered by unseeded Col type I-HYA scaffolds; Control group: the ChD's were left to heal spontaneously without any treatment. Macroscopical, histological and immunohistochemical analyses of the ChD's were performed 12 months after the treatment. In all treated groups, the chondrocytes were capable to proliferate and produce the cartilage extracellular matrix, including proteoglycans and type II collagen, as compared to the control "untreated" group. On the other hand, the production of hyaline-like cartilage tissue confirmed that both therapeutic methods using autologous chondrocytes can be applied successfully for the treatment of chondral defects in rabbits.

Key words: rabbits, articular cartilage defect, chondrocyte implants, collagen, hyaluronan

\section{INTRODUCTION}

Articular hyaline cartilage is a specialized connective tissue important for the distribution of pressure and shear forces within joints with a specific role in animal locomotion

\footnotetext{
*Corresponding author: e-mail: denisa.harvanova@upjs.sk
} 
[1]. Mature articular cartilage has a limited potential for the repair of critical-sized defects because of its avascularity and the absence of stem cells [2]. The response of the normal articular cartilage to damage or degeneration is frequently partial and repair of the damaged tissue is incomplete. Surface defects of articular cartilage do not heal spontaneously and usually turn to extensive degeneration [3]. It was observed that despite the limited ability of chondrocytes to migrate from marginal zones into the defective site, they cannot multiply in these locations and produce macromolecules needed for the repair of the organized intercellular matrix typical of normal articular cartilage [4].

Cartilage properties result from its microscopic structure. Detailed studies of morphology and biology of mature cartilage showed that it is a highly organized structure. Complex connections between the chondrocytes and the matrix are maintained actively and are responsible for the preservation of the shape and function of the tissue owing to the structural character of the solid component (e.g.: collagen, proteoglycans and glycoproteins). Therefore, the tissue that would reconstruct correctly the damaged surface of the articular cartilage has to replicate these structures very precisely thus cartilaginous tissue defects could be repaired.

Current scientific trends present new possibilities for the repair of cartilage defects. Transplantation of autologous or allogenous chondrocytes, synovial mesenchymal stem cells, and biodegradable scaffolds are the methods that have been tested experimentally and clinically [5-11]. Implants seeded with chondrocytes cultured in vitro support the production of the extracellular matrix by chondrocytes, mainly glycosaminoglycans and type II collagen [12,13]. The implantation of chondrocyte-collagen composites into cartilage defects has proved a promising method of cartilage repair $[14,15]$ and numerous in vivo studies in animals have shown that hyaluronan-based scaffolds seeded with autologous chondrocytes are useful for inducing the formation of hyaline-like cartilage tissue and are reabsorbed in the absence of an inflammatory response [16,17]. The aims of our study were to investigate a repair process of artificially created cartilage defects in rabbits treated by autologous and allogenous chondrocytes in a suspension in fibrin glue Beriplast ${ }^{\circledR}$ or seeded on Collagen type I-Hyaluronan (Col type I-HYA) scaffolds. Chondral defects (ChD's) were created in such a manner as not to affect the zone of calcified cartilage in a non-load-bearing area of the medial condyle of the distal femur. The healing process of ChD's was evaluated macroscopically, as well as by histological and immunohistochemical analyses 12 months after the treatment.

\section{MATERIALS AND METHODS}

\section{Animal care}

This study was performed at the University of Veterinary Medicine Košice, Slovakia respecting the guidelines for animal experiments with the approval of the Ethical Committee. This experiment was carried out on 15 domestic rabbits assigned to four treated groups and the untreated "control" group ( $n=3$ in each). Within four weeks, two surgical procedures were performed. In both cases, the rabbits were premedicated with an intramuscular injection of 1\% ketamin hydrochloride (Narkamon inj. a.u.v., 
Léčiva, CZ) and 2\% xylasin hydrochloride (Rompun amp. a.u.v, Bayer, Turkey) at doses of $40 \mathrm{mg} / \mathrm{kg} \mathrm{BW}$ and $4 \mathrm{mg} / \mathrm{kg} \mathrm{BW}$, respectively and anesthesia was maintained with 2.0 $\%$ isoflurane at $2 \mathrm{l} / \mathrm{min}$. constant oxygen flow.

The first surgery was performed on the knee joint of the left hind leg to obtain articular cartilage from a non-weight bearing area of the medial femur condyle. All samples of articular cartilage were harvested for 4 weeks in vitro cultivation of chondrocytes. One month after the first surgery, on the same knee joint, circular chondral defects (3 $\mathrm{mm}$ in diameter) were created artificially at the non-weight bearing area of the medial femur condyle using a metal puncture needle (Chirana, SR) during arthrotomy of the knee joint. The ChD's were made of a desirable size and shape. While creating the ChD's, our aim was to prevent their penetration into the vascularized subchondral zone as the zone of calcified cartilage should remain intact, because deformations of the vascularized layer are accompanied by a bloody discharge what induces an "undesired" non-specific healing process.

One month after the first surgical procedure, the second operation was performed under identical conditions, using the same procedure as described previously. The ChD's created artificially during the first surgery were treated as follows:

$1^{\text {st }}$ group: The ChD's were filled with autologous chondrocytes seeded on Col type I-HYA scaffolds. The scaffolds were fixed to the ChD's by fibrin glue Beriplast ${ }^{\circledR}$ (Centeon Pharma GmbH). The scaffolds corresponded to the size, shape and depth of the chondral defects, and they were implanted into the ChD's in such a fashion that the surface seeded with cultured chondrocytes was directed into the defect base, while the surface without cultured chondrocytes was oriented to the synovial cavity of the femur.

$2^{\text {nd }}$ group: The ChD's were filled with allogenous chondrocytes seeded on Col type I-HYA scaffolds. The same way as in Group 1 were used for implantation of the scaffolds.

$3^{\text {rd }}$ group: The ChD's were filled with a suspension of autologous chondrocytes in fibrin glue Beriplast ${ }^{\circledR}$ and they were immediately covered by Col type I-HYA scaffolds.

$4^{\text {th }}$ group: The ChD's were filled with a suspension of allogenous chondrocytes in fibrin glue Beriplast ${ }^{\circledR}$ and they were immediately covered by Col type I-HYA scaffolds.

Control group: The ChD's were left to heal spontaneously without any treatment. Immediately after treatment, the knee joint was stabilized with a modified Robert Jones bandage for 2 weeks. All rabbits were sacrificed by an intravenous injection of veterinary euthanasia solution (T-61, Hoechst, Somerville, NJ) for the collection of samples 12 months after the treatment.

\section{Allogenous and autologous chondrocyte isolation and culture, and Col type I-HYA Scaffold preparation}

Specific procedures for the isolation and cultivation of chondrocytes and the preparation of Col type I-HYA scaffolds were as described by Harvanova et al. [18]. Briefly, circular fragments of rabbit cartilage ( $3 \mathrm{~mm}$ in diameter) were digested by bacterial collagenase 
type II $(1 \mathrm{mg} / \mathrm{mL})$ (Gibco BRL $\left.{ }^{\circledR}\right)$ in Nutrient mixture F-12 medium (Gibco BRL ${ }^{\circledR}$ ) supplemented with $1 \%(\mathrm{v} / \mathrm{v})$ antibiotic/antimycotic solution for 16-20 hours. The obtained chondrocytes were collected and cultivated in Nutrient mixture F-12 medium supplemented with $20 \%(\mathrm{v} / \mathrm{v})$ fetal bovine serum $\left(\mathrm{Gibco} B R L^{\circledR}\right), 1 \%(\mathrm{v} / \mathrm{v})$ insulinselenium-transferin A $\left(\mathrm{Gibco} B \mathrm{BR}^{\circledR}\right), 1 \%(\mathrm{v} / \mathrm{v})$ antibiotic/antimycotic solution at $37^{\circ} \mathrm{C}$ in humidified air with $5 \% \mathrm{CO}_{2}$ for one month. Isolated chondrocyte cultures were passaged before confluence was obtained with trypsin-EDTA (Gibco BRL ${ }^{\circledR}$ ) and the medium was exchanged every three days. In the $3^{\text {rd }}$ and $4^{\text {th }}$ group, autologous and allogenous chondrocytes were used for the in vivo application with fibrin glue Beriplast ${ }^{\circledR}$ at density of $0.65-0.8 \times 10^{6}$ per $\mathrm{ml}$ and seeded on the Col type I-HYA scaffold, respectively.

Enzymatically treated fibrous collagen type I (bovine Collagen type I from Achilles tendon, Hypro, Otrokovice, Czech Republic) was mixed with 0,5 M solution of acetic acid and aqueous solution of sodium hyaluronate $(10 \mathrm{mg} / \mathrm{ml}, 1500 \mathrm{kDa}$, CONTIPRO Ltd., Dolní Dobrouč, Czech Republic). Starch dialdehyde 2\% (v/v) aqueous solution was added to the collagen/hyaluronan complex and homogenized in a blender at 1400 RPM for 1 minute, pre-frozen for 12 hours and freeze dried (JOUAN LP3) at $-45^{\circ} \mathrm{C}$, $2 \times 10^{-2} \mathrm{mBa}$ for 6-8 hours. After lyophilisation, scaffolds were sealed in polyethylene bags and sterilized by ${ }^{60} \mathrm{Co}$ radiation with a dose of $30 \mathrm{kGy}$. Lyophilized scaffolds were cut to a desired shape ( $3 \mathrm{~mm}$ in diameter) and were left in the culture medium for 1 hour before in vitro cultivation. In the $1^{\text {st }}$ and $2^{\text {nd }}$ group, autologous and allogenous chondrocytes were seeded on the Col type I-HYA scaffold in at density of 0.47-0.6 $\times 10^{6}$ per $\mathrm{cm}^{2}$ and were cultured at $37^{\circ} \mathrm{C}$ in humidified air with $5 \% \mathrm{CO}_{2}$ for 4 weeks, respectively. The culture medium was exchanged every three days.

\section{Locomotory activities}

Evaluation was based on the time needed to full load limb recovery after treatment and on monitoring of patella position, septic arthritis, production of exudate compactness of suture, and infection of wounds which can also reflect the status of the defect repair.

\section{Macroscopic evaluation}

The gross appearance of the ChD's was evaluated for color, integrity, contour and smoothness of the surface.

\section{Histological and immunohistochemical analyses}

The specimens of treated medial condyles of the distal femur in each rabbit were fixed in $10 \%$ phosphate-buffered formalin (Sigma-Aldrich ${ }^{\circledR}$, Slovak Republic) for $48 \mathrm{~h}$. Subsequently, they were washed in water and decalcified in $25 \%$ Chelaton III $(\mathrm{v} / \mathrm{v}) \mathrm{pH}$ 7.4 (Bioptika, Italy) at $37^{\circ} \mathrm{C}$ for 7 days. After decalcification, the samples were washed in water for $24 \mathrm{~h}$, embedded in paraffin wax, and $15 \mu \mathrm{m}$ thick slices were cut sagittally, and were stained in situ with Haemotoxylin-Eosin (H\&E) and Safranine O (specific for proteoglycans). Immunohistochemical staining was carried out using antibodies against collagen type II fibres (Rabbit Anti-Human Collagen type II, BIODESIGN 
International, Saco, ME USA) and porcine immunoglobulin against human IgG tagged with florescein-isothiocyanate (SwAHu/IgG-FITC, SeVac, Prague, Czech Republic). Both antibodies were diluted 1:100 in 1\% phosphate buffered saline $(10 \mathrm{mM}$ sodium phosphate, $0.15 \mathrm{M}$ sodium chloride, $\mathrm{pH}$ 7.4).

The evaluation was performed by light microscopy and fluorescence microscopy using Olympus advanced inverted microscope IX-71 with an improved fluorescence illuminator. The histological sections were examined for the quality of the repair process and were graded with use of histological scale described by [6]. All stained slides were evaluated in a blind test by three experienced histologists.

\section{RESULTS}

\section{Locomotory activities}

Despite repeated arthrotomy, none of the animals showed complications in relation to patella luxation, septic arthritis and excessive production of exudate, dehiscence of sutures or secondary infection of wounds. After the second operation, we observed that the rabbits spontaneously put less weight on the operated limb. The full load and extension of the hind leg recovered completely at the end of the $3^{\text {rd }}$ week after treatment, it means, one week after the bandage removal. Moreover, pain as a factor which significantly limits movements, is not expected in this type of defect (partial cartilage loss) due to the avascular and aneural character of the articular cartilage.

\section{Macroscopic evaluation}

The patellar joints were filled with a clear viscous synovial fluid in all rabbits. In all treated groups, neither detachment of the Col type I-HYA scaffolds (except for a severally irregular surface of the treated $\mathrm{ChD}$ in one rabbit in the $4^{\text {th }}$ group) nor signs of articular surface damage (such as chondromalacia, osteoarthritis or synovitis) or hypertrophy were found. In the $1^{\text {st }}$ and $3^{\text {rd }}$ group treated by the autologous or allogenous chondrocytes, respectively, the ChD's have been filled with smooth cartilaginous tissue of a color similar to healthy cartilage (Fig. 1a). The ChD's were completely filled in 3 rabbits (one in the $1^{\text {st }}$ group and two in the $3^{\text {rd }}$ group), but one edge of the scaffolds was not completely integrated with the ChD's in the other rabbits. On the other hand, in the $2^{\text {nd }}$ and $4^{\text {th }}$ group treated with the suspension of autologous or allogenous chondrocytes, respectively, we have found just partial healing of the ChD's in all rabbits (Fig. 1b). In the control group, no signs of cartilage reparation processes were observed and the ChD's retained sharp edges even 12 months after surgery (Fig. 1c). Surprisingly, in the rabbit no. 15 , the $\mathrm{ChD}$ was covered with a whitish tissue that did not resemble the cartilage tissue.

\section{Histological and immunohistochemical analyses}

Results of the histological examination of all stained slides are presented in Table 1. In the $1^{\text {st }}$ group, the ChD's were filled with a hyaline-like cartilage tissue (HyLCa) (Fig. $2 \mathrm{a}$ ), but the intensity of Safranin $\mathrm{O}$ staining was high in all layers (deep, middle and 


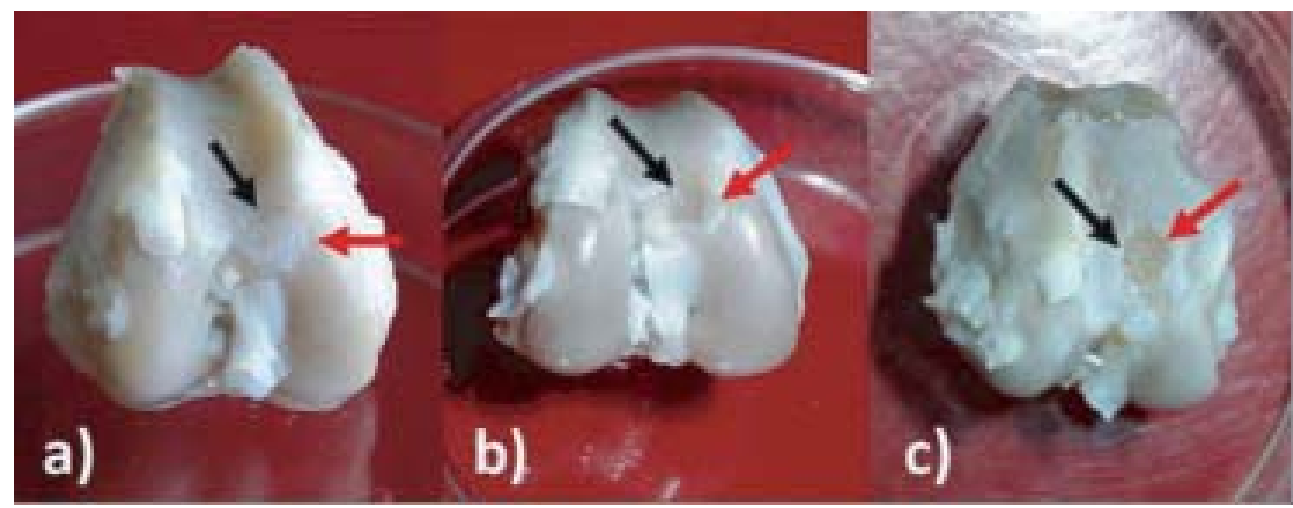

Figure 1. Macroscopic view of the chondral defects repaired a) by autologous chondrocyte seeded on Col type I-HYA scaffold (1st group), b) by suspension of allogenous chondrocytes in a fibrin glue (4th group) c) without any treatment (Control group). Arrows show the position of the chondral defects.

surface layer) of the $\mathrm{ChD}$ (Fig. 2b) only in rabbit no. 3. Except for HyLCa, we have also observed sporadic segments of fibrocartilage ( $\mathrm{FiCa}$ ), particularly in the surface layer of the ChD's in rabbit no. 1 and no. 2 from the same group. Safranin O staining revealed a relatively high production of proteoglycans (PG's) and collagen type II fibres, in the deep layer, but lower intensity of staining has been exhibited in the surface layer of the ChD's. Chondrocytes in the deep layer have a round shape and their density was higher as compared to the surface layer of the ChD's. Immunohistochemical staining confirmed the presence of cells with the chondrocyte phenotype in all ChD's (Fig. 2c). In rabbit no. 1, a slight hypertrophy of HyLCa was detected probably due to the shape of the scaffold which could be not completely suitable for the insertion into the defect. All in all, a local inflammatory reaction was not observed in all cases.

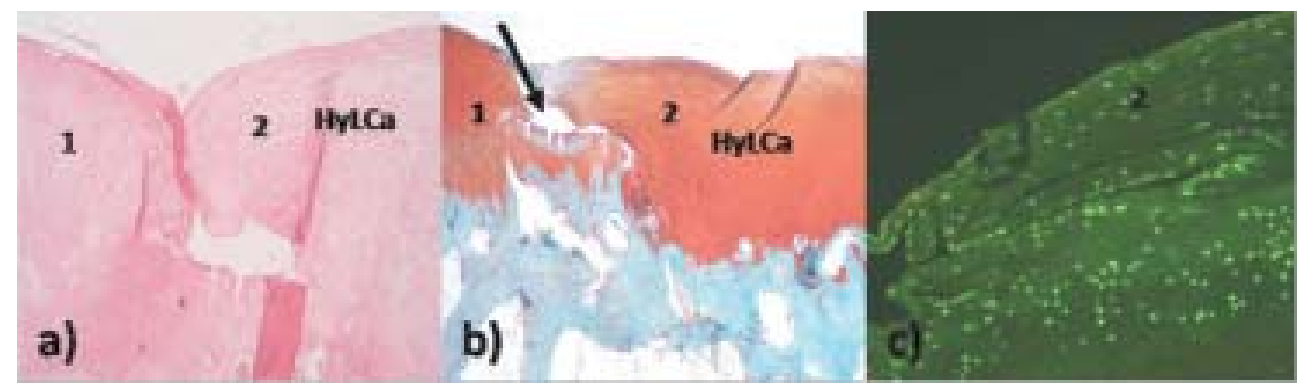

Figure 2. Histological and immunohistochemical analyses of the chondral defects repaired by autologous chondrocyte seeded on Col type I-HYA scaffold (1st group) a) H\&E staining, 150x magnification b) Safranin O staining, 100x magnification, arrow shows a weakened adhesion of the autologous chondrocyte seeded on Col type I-HYA scaffold to the native chondral cartilage c) Immunohistochemical staining, 200x magnification. (HyLCa = hyaline-like cartilage tissue, 1native chondral cartilage, 2-autologous chondrocytes seeded on Col type I-HYA scaffold)

In the $2^{\text {nd }}$ group, apparently lower numbers of cells with the chondrocyte phenotype occupied the ChD's (Fig. 3a), as well as decreased production of PG's (Fig. 3b) and collagen type II fibers (Fig. 3c) were found than in the $1^{\text {st }}$ group. In addition, the ChD's healed with both types of cartilage tissues, but predominantly by FiCa. A local 
Table 1. Histological grading scale for the repair of the chondral defects in individual rabbits.

\begin{tabular}{|c|c|c|c|c|c|c|c|c|c|c|c|c|c|c|c|c|}
\hline \multirow{2}{*}{$\begin{array}{l}\text { Category } \\
\text { Number of rabbit }\end{array}$} & \multirow[t]{2}{*}{ Points } & \multicolumn{3}{|c|}{$1^{\text {st }}$ group } & \multicolumn{3}{|c|}{$2^{\text {nd }}$ group } & \multicolumn{3}{|c|}{$3^{\text {rd }}$ group } & \multicolumn{3}{|c|}{$4^{\text {th }}$ group } & \multicolumn{3}{|c|}{$\begin{array}{l}\text { Control } \\
\text { group }\end{array}$} \\
\hline & & 1 & 2 & 3 & 4 & 5 & 6 & 7 & 8 & 9 & 10 & 11 & 12 & 13 & 14 & 15 \\
\hline \multicolumn{17}{|l|}{ Cell morphology } \\
\hline Hyaline cartilage & 0 & & & 0 & & & & & 0 & 0 & & & & & & \\
\hline $\begin{array}{l}\text { Mostly hyaline } \\
\text { cartilage }\end{array}$ & 1 & 1 & 1 & & & & & 1 & & & & & & & & \\
\hline Mostly fibrocartilage & 2 & & & & 2 & 2 & 2 & & & & 2 & 2 & 2 & & & 2 \\
\hline Mostly non-cartilage & 3 & & & & & & & & & & & & & & & \\
\hline Non-cartilage & 4 & & & & & & & & & & & & & 4 & 4 & \\
\hline \multicolumn{17}{|c|}{ Matrix staining (metachromatic) } \\
\hline Normal & 0 & & & 0 & & & & & 0 & 0 & & & & & & \\
\hline Slighty reduced & 1 & 1 & 1 & & & & & 1 & & & & & & & & \\
\hline Markedly reduced & 2 & & & & 2 & 2 & 2 & & & & 2 & 2 & 2 & & & \\
\hline $\begin{array}{l}\text { No metachromatic } \\
\text { staining }\end{array}$ & 3 & & & & & & & & & & & & & 3 & 3 & 3 \\
\hline \multicolumn{17}{|l|}{ Surface regularity } \\
\hline Smooth $(>3 / 4)$ & 0 & 0 & 0 & 0 & & & & & 0 & 0 & & & & & & \\
\hline Moderate $(>1 / 2-3 / 4)$ & 1 & & & & & & 1 & 1 & & & & & & & & \\
\hline Irregular (1/4-1/2) & 2 & & & & 2 & 2 & & & & & 2 & & 2 & & & \\
\hline Severely irregular & 3 & & & & & & & & & & & 3 & & 3 & 3 & 3 \\
\hline \multicolumn{17}{|l|}{ Thickness of cartilage } \\
\hline$>2 / 3$ & 0 & & & 0 & & & & & 0 & 0 & & & & & & \\
\hline $1 / 3-2 / 3$ & 1 & 1 & 1 & & 1 & 1 & 1 & 1 & & & 1 & 1 & 1 & & & 1 \\
\hline$<1 / 3$ & 2 & & & & & & & & & & & & & 2 & 2 & \\
\hline \multicolumn{17}{|c|}{ Integration of donor with host adjacent cartilage } \\
\hline Both edges integrated & 0 & & & 0 & & & & 0 & 0 & 0 & & & & & & \\
\hline One edge integrated & 1 & 1 & 1 & & 1 & 1 & 1 & & & & 1 & 1 & 1 & & & 1 \\
\hline $\begin{array}{l}\text { Neither edge } \\
\text { integrated }\end{array}$ & 2 & & & & & & & & & & & & & 2 & 2 & \\
\hline Total maximum & 14 & 4 & 4 & 0 & 8 & 8 & 7 & 4 & 0 & 0 & 8 & 9 & 8 & 14 & 14 & 10 \\
\hline
\end{tabular}

inflammatory reaction was not confirmed by histological analysis, what indicates that the allogenous chondrocytes did not cause the scaffold rejection accompanied by its lacked mechanical stability in the defect leading to inflammation.

In the $3^{\text {rd }}$ group, the ChD's were filled completely with HyLCa in two rabbits (no. 8 and no. 9). In the deep layer of the ChD's, the cells resembling chondrocytes of the native cartilage tissue have a round shape (Fig. 4a, 4b). The surface layer of the ChD's showed the presence of collagen type II fibers produced by chondrocytes seeded on Col type I-HYA scaffold as in the $1^{\text {st }}$ group. The intensity of PG's was low in the surface layer, particularly at the edges of the ChD's, but in the middle and deep layer were higher (Fig. $4 \mathrm{c}, 4 \mathrm{~d})$. Immunohistochemical staining proved the presence of a cellular population of the chondrocyte phenotype in the ChD's (Fig. 4e).

In the $4^{\text {th }}$ group, we have observed only partial regeneration of the ChD's in two rabbits (no. 10 and no. 12). A severely irregular surface of the treated ChD was found in the rabbit no. 11. Reparation of the ChD's was incomplete and damage was located mostly at the edges of the defects. HyLCa has been observed in the middle and deep layer of the defects, but the periphery of the ChD's was filled with FiCa. The production of PG's and the density of cells with the chondrocyte phenotype were low. Fibrin glue components without the cell population were seen in these $\mathrm{ChD}^{\prime}$ 's, too. 


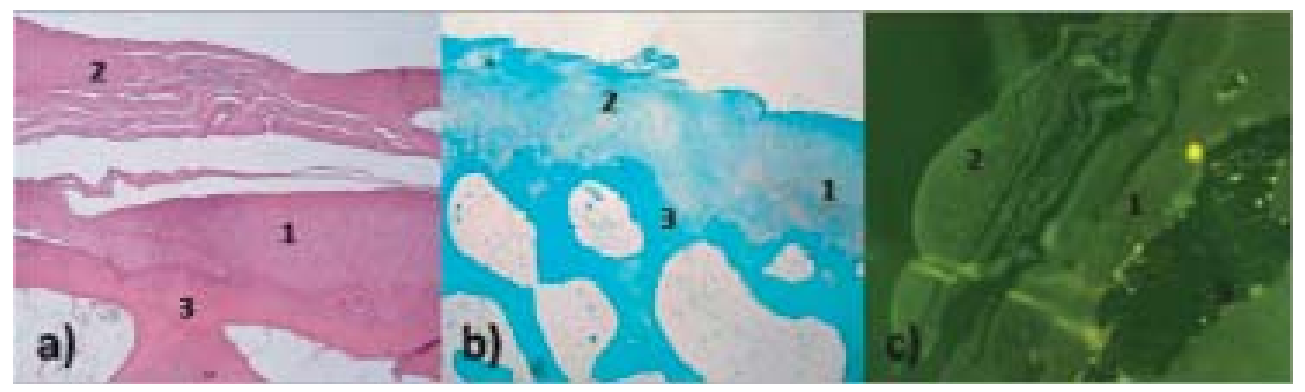

Figure 3. Histological and immunohistochemical analyses of the chondral defects repaired by allogenous chondrocyte seeded on Col type I-HYA scaffold (2nd group) a) H\&E staining, 150x magnification, b) Safranin O staining, 100x magnification, very low production of PG's. c) Immunohistochemical staining, 100x magnification, production of collagen type II localised mainly in deep layer of the chondral defect. (PG's = proteoglycans, 1-native chondral cartilage, 2-allogenous chondrocytes seeded on Col type I-HYA scaffold, 3 - subchondral bone)

In the control group, the ChD's were left to heal spontaneously. The defects were empty in 2 rabbits (no. 13 and no. 14). In the rabbit no. 15, non-specific repair mechanisms were observed in the deep layer of the $\mathrm{ChD}$ by the formation of FiCa. Neither the production of PG's nor collagen type II fibers were found in this group.

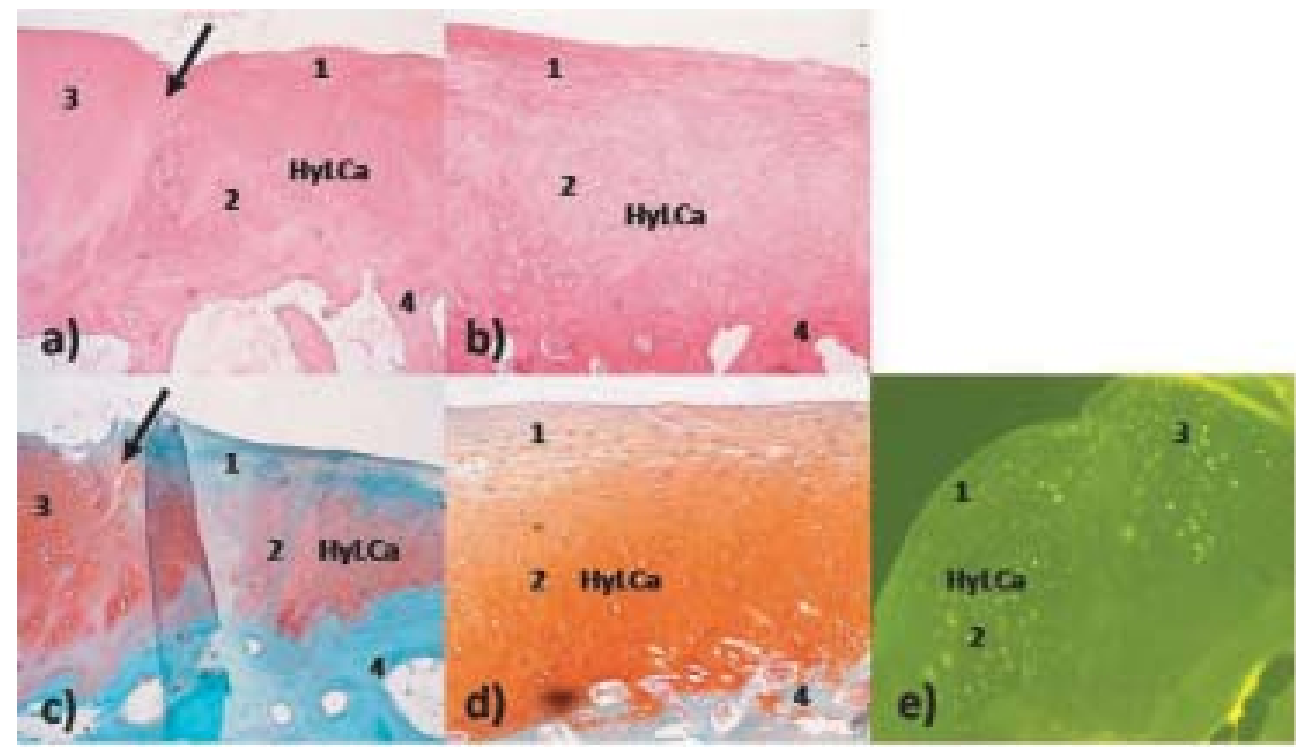

Figure 4. Histological and immunohistochemical analyses of the chondral defects repaired by a suspension of autologous chondrocytes in fibrin glue (3rd group) a) H\&E staining, 100x magnification b) H\&E staining, 150x magnification, c) Safranin O stain, magnification 100x, surface layer created by collagen type I fibres from the scaffold, and marginal zone of the chondral defect with a low production of PG's, and deep layer of the defect is repaired by HyLCa d) Safranin O stain, magnification 150x, deep and middle layer of the chondral defect with high production of PG's d) Immunohistochemical staining, 150x magnification. (HyLCa $=$ hyalinelike cartilage tissue, $\mathrm{PG}^{\prime} \mathrm{s}=$ proteoglycans, 1 - surface layer of the chondral defect, 2 - deep layer of the condral defect, 3 - deep layer of the native chondral cartilage, 4 - subchondral bone, arrows indicate the marginal zones of the chondal defect) 


\section{DISCUSSION}

In the last few years, a great effort was made to define a suitable method for the implantation of chondrocytes into the defective cartilage in order to support the regeneration of cartilage tissue. Studies comparing methods for cartilage tissue reconstruction using autologous chondrocytes, as well as allogenous chondrocytes are lacking. Therefore, we have decided to use two different methods of implantation of autologous and allogenous chondrocytes into the ChD's: (a) a suspension of chondrocytes in a fibrin glue covered by the Col type I-HYA scaffolds, and (b) chondrocytes seeded on the Col type I-HYA scaffolds fixed with a fibrin glue. In addition, Lee et al. [19] found that chondrocytes cultured for 4 weeks are able to produce higher amounts of hyaline cartilage after their implantation into chondral defects than these cultured for a significantly shorter time (only 12h). Therefore, the culturing period of chondrocytes for one month was chosen in our study.

Different scaffolds were used as cell or tissue carriers for cartilage tissue engineering so far [20-23]. The major advantage of collagen scaffolds, which were used in our experiment, is their tissue abundance and a highly organized structure. It is known, that porous three-dimensional structures consisting of collagen fibers support the viability of chondrocytes and their production of extracellular matrix in vitro. Collagen contains cell-adhesion domain sequences that induce specific cellular interactions [24]. Substrate-bonded hyaluronan exhibits size-dependent stimulation of chondrogenic differentiation and also improves the proliferative activity of cultured chondrocytes [25]. As previously published [26-28], small amounts of hyaluronan $(2 \% \mathrm{w} / \mathrm{w})$ in threedimensional collagen scaffolds can enhance chondrogenesis. Based on our previous study [18], we can corroborate that the Col type I-HYA scaffolds had not any adverse effects on chondrocyte viability, morphology and phenotype during long term (2-3 months) in vitro cultivation. Moreover, Lin et al. [23] found that chondrocytes seeded on Hyaluronan/Collagen II microspheres could exhibit a high activity in repairing a cartilage defect, what is in accordance with our findings.

On the other hand, suspension with chondrocytes can be injected with ease to the defect or target site. Defects orientated downwards are influenced by the gravitational forces which can affect the initial distribution of transplantated chondrocytes and may have an important role in the final clinical outcome [29]. This phenomenon was not observed in our study, but the partial detachment of the Col type I-HYA scaffold was found in one rabbit treated with the suspension of allogenous chondrocytes in fibrin glue. By our opinion, adhesive properties of the fibrin glue could be altered due to its dilution with a medium of cultured chondrocytes. All in all, comparing autologous vs. allogenous chondrocyte application, better proliferation of cells with the chondrocyte fenotype and production of PG's, as well as the creation of HyLCa were observed in both groups treated with autologous chondrocytes. Hong et al. [30] hypothesized that autologous structures have better biocompatibility with native tissues, which was corroborated with our findings too.

As a limitation of this study can be considered that, a small number of experimental animals (only 3 rabbits per group) was used. This discouraged the use of statistical 
analysis within the groups thus individual examination was chosen to present our findings instead. Moreover, rabbits are not an optimal animal model for the evaluation of the ChD's due to the relatively small dimensions of the knee joint and a thin layer of chondrium, which is not thicker than $1 \mathrm{~mm}$.

In all treated groups, the chondrocytes were capable to proliferate and produce the cartilage extracellular matrix, including proteoglycans and type II collagen fibers, as compared to the control "untreated" group. The fibrin glue ensured a sufficient fixation of the scaffolds when it was applied undiluted, but its fixative properties could be altered by a medium of chondrocytes added thus further investigations with a higher number of animals involved are required. For this reason, it can be concluded that the autologous chondrocytes seeded on a Collagen type I-Hyaluronan scaffold represents a very successful way of treatment of articular cartilage defects in rabbits.

\section{ACKNOWLEDGEMENT}

This research was supported by VEGA grant no. 1/0406/12 from the Ministry of Education, Science, Research and Sport of the Slovak Republic

\section{REFERENCES}

1. Adam A, Pohunková H, Klézl Z, Pešáková V, Čech O: Use of bioimplants to replace cartilage. Part II: application of implants in animal experiments. Acta Chir Orthop Traumtol Cech 1997, 64:207-210.

2. Brittberg M, Nilsson A, Lindahl A, Ohlsson C, Peterson L: Rabbit articular cartilage defects treated with autologous cultured chondrocytes. Clin Orthop1996, 326:270-83.

3. Buckwalter JA: Articular cartilage: injuries and potential for healing. J Orthop Sports Phys Ther 1998, 28:192-202.

4. Shapiro F, Koide S, Glimcher MJ: Cell origin and differentiation in the repair of full thickness defects of articular cartilage. J Bone Joint Surg Am 1993, 75:532-553.

5. Brittberg M, Lindahl A, Nilsson A, Ohlsson C, Isaksson O, Peterson L: Treatment of deep cartilage defects in the knee with autologous chondrocyte transplantation. N Engl J Med 1994, 331:889-895.

6. Wakitani S, Goto T, Pineda SJ, Young RG, Mansour JM, Caplan AI, Goldberg VM: Mesenchymal cell-based repair of large, full-thickness defects of articular cartilage. J Bone Joint Surg Am 1994, 76:579-592.

7. Trippel SB: Autologous chondrocyte transplantation. N Engl J Med 1995, 332:539-540.

8. Hardingham T, Tew S, Murdoch A: Tissue engineering: chondrocytes and cartilage. Arthritis Res 2002, 4:S63-S68.

9. Plonczak M, Czubak J, Kawiak J: Repair of articular cartilage defects with cultured chondrocytes on polysulphonic scaffold: experimental studies in rabbits. Transplant Proc 2006, 38:320-322.

10. Furth ME, Atala A, Van Dyke ME: Smart biomaterials design for tissue engineering and regenerative medicine. Biomaterials 2007, 28:5068-5073.

11. Harvanová D, Tóthová T, Šarišský M, Amrichová J, Rosocha J: Isolation and characterization of synovial mesenchymal stem cells. Folia Biol (Praha) 2011, 57:119-124. 
12. Pavesio A, Abatangelo G, Borrione A, Brocchetta D, Hollander AP, Kon E, Torasso F, Zanasi S, Marcacci M: Hyaluronan-based scaffolds (Hyalograft C) in the treatment of knee cartilage defects: preliminary clinical findings. Novartis Found Symp 2003, 249:203-217.

13. Trattnig S, Ba-Ssalamah A, Pinker K, Plank C, Vecsei V, Marlovits S: Matrix-based autologous chondrocyte implantation for cartilage repair: noninvasive monitoring by high-resolution magnetic resonance imaging, Magn Reson Imaging 2005, 23:779-787.

14. Masuoka K, Asazuma T, Ishihara M, Sato M, Hattori H, Ishihara M, Yoshihara Y, Matsui T, Takase B, Kikuchi M, Nemoto K: Tissue engineering of articular cartilage using an allograft of cultured chondrocytes in a membrane-sealed atelocollagen honeycomb-shaped scaffold (ACHMS scaffold). J Biomed Mater Res B Appl Biomater 2005, 75:177-184.

15. Willers C, Chen J, Wood D, Xu J, Zheng MH: Autologous chondrocyte implantation with collagen bioscaffold for the treatment of osteochondral defects in rabbits. Tissue Eng 2005, 11:1065-1076.

16. Grigolo B, Roseti L, Fiorini M, Fini M: Transplantation of chondrocytes seeded on a hyaluronan derivative (hyaff-11) into cartilage defects in rabbits. Biomaterials 2001, 22:2417-24.

17. Patti AM, Gabriele A, Vulcano A, Ramieri MT, Della Rocca C: Effect of hyaluronic acid on human chondrocyte cell lines from articular cartilage, Tissue Cell 2001, 33:294-300.

18. Harvanová D, Rosocha J, Bakoš D, Švihla R, Vaško G, Horňák S, Ledecký V, Gromošová S, Cibur P, Raši R: Collagen/hyaluronan membrane as a scaffold for chondrocytes cultivation. Biologia 2009, 64:1032-1038.

19. Lee CR, Grodzinsky AJ, Hsu HP, Spector M: Effects of a cultured autologous chondrocyteseeded type II collagen scaffold on the healing of a chondral defect in a canine model. J Orthop Res 2003, 21:272-281.

20. Lin LC, Chang SJ, Kuo SM, Niu GCC, Keng HK, Tsai PH: Preparation and evaluation of b-TCP/polylactide microspheres as osteogenesis materials, J Appl Polym Sci 2008, 108:3210-3217.

21. Tan H, Wu J, Lao L, Gao C: Gelatin/chitosan/hyaluronan scaffold integrated with PLGA microspheres for cartilage tissue engineering. Acta Biomater 2009, 5:328-337.

22. Singh M, Sandhu B, Scurto A, Berkland C, Detamore MS: Microsphere-based scaffolds for cartilage tissue engineering: using subcritical $\mathrm{CO}_{2}$ as a sintering agent. Acta Biomater 2010, 6:137-143.

23. Lin LC, Chang SJ, Lin CY, Lin YT, Chuang CW, Yao CH, Kuo SM: Repair of Chondral Defects With Allogenous Chondrocytes-Seeded Hyaluronan/Collagen II Microsphers in Rabit Model. Artif Organs 2012, 36:E102-E109.

24. Silver FH, Pins G: Cell growth on collagen: a review of tissue engineering using scaffolds containing extracellular matrix, J Long Term Eff Med Implants 1992, 2:67-80.

25. Kujawa MJ, Carrino DA, Caplan AI: Substrate-bonded hyaluronic acid exhibits a sizedependent stimulation of chondrogenic differentiation of stage 24 limb mesenchymal cells in culture. Dev Biol 1986, 114:519-528.

26. Allemann F, Mizuno S, Eid K, Yates KE, Zaleske D, Glowacki J: Effects of hyaluronan on engineered articular cartilage extracellular matrix gene expression in 3-dimensional collagen scaffolds. J Biomed Mater Res 2001, 55:13-19.

27. Chang $\mathrm{CH}$, Kuo TF, Lin CC, Chou CH, Chen KH, Lin FH, Liu HC: Tissue engineering- 
based cartilage repair with allogenous chondrocytes and gelatin-chondroitin-hyaluronan tricopolymer scaffold: a porcine model assessed at 18, 24, and 36 weeks. Biomaterials 2006, 27:1876-1888.

28. Ko CS, Huang JP, Huang CW, Chu IM: Type II collagen-chondroitin sulfate-hyaluronan scaffold cross-linked by genipin for cartilage tissue engineering. J Biosci Bioeng 2009, 107:177-182.

29. Sohn DH, Lottman LM, Kim SG, Pedowitz RA, Coutts RD, Sah RL: Effect of gravity on localization of chondrocytes implanted in cartilage defects. Clin Orthop Relat Res 2002, 394:254-262.

30. Hong HJ, Lee JS, Choi JW, Min BH, Lee HB, Kin CH: Transplantation of Autologous Chondrocytes Seede on a Fibre/Hyaluronan Composite Gel Into Trachela Cartilage Defects In Rabbits. Artif Organs 2012, 36:998-1006.

\section{REPARACIJA DEFEKATA HRSKAVICE KUNIĆA AUTOLOGNIM I ALOGENIM HONDROCITIMA ZASEJANIM NA KOLAGEN/ HIJALURONAN OSNOVU ILI SUSPENDOVANIM U FIBRINSKOM LEPKU}

HORŇÁK Slavomír, HARVANOVÁ Denisa, LEDECKÝ Valent, HLUCHÝ Marian, VALENČÁKOVÁ-AGYAGOSOVÁ Alexandra, AMRICHOVÁ Judita, ROSOCHA Ján², VAŠKO Gabriel, ŠVIHLA Róbert, PETROVIČ Vladimír

Cilj studije je bio da se verifikuje in vivo preživljavanje in vitro kultivisanih autolognih i alogenih hondrocita suspendovanih u fibrinski Beriplast ${ }^{\circledR}$ lepak ili na kolagen Hyaluronan tip I (Col type I-HYA) osnovu radi regeneracije oštećenja zglobne hrskavice kod kunića. Ispitivanje je obavljeno na 15 domaćih kunića, odabranih slučajnim izborom koji su podeljeni u pet grupa (3 po grupi) kod kojih su veštački izazvana oštećenja hrskavice (ChD), tretirana na različite načine. Oštećenja su napravljena na površinama koje nisu noseće na medijalnom kondilusu distalnog femura, a tretman je podrazumevao: prva i treća grupa: ChD su punjene sa autolognim ili alogenim hondrocitima zasejanim na Col tip I-HYA osnovu. Osnove su fiksirane na ChD pomoću fibrinskog lepka Beriplast®; druga i četvrta grupa: oštećenja su punjena suspenzijom autolognih ili alogenih hondrocita u fibrinskom Beriplast ${ }^{\circledR}$ lepku, a neposredno posle toga, prekriveni su sa nezasejanom Col tip I-HYA osnovom; kontrolna grupa: oštećenja su ostavljena da spontano zarastu, bez tretmana. Dvanaest meseci posle tretmana obavljene su makroskopske, histološke i imunohistološke analize promena. Kod svih životinja tretiranih grupa, hondrociti su bili sposobni da proliferišu i proizvode ekstracelularni matriks hrskavice, uključujući proteoglikane i II tip kolagena u poređenju sa kontrolnom "netretriranom" grupom. Sa druge strane, proizvodnja hrskavičavog tkiva nalik na hijalin potvrđuje da se oba terapijska metoda koji koriste autologne hondrocite mogu da uspešno primene u tretiranju defekata hrskavice kod kunića. 